\title{
PROXIMATE COMPOSITION OF SORGHUM GRAIN AND PEARL MILLET
}

\section{G. RAJALAKSHMI, K. S. GNANALAKSSHMI, D. BASKARAN \& M. ABDUL REIYAZ}

Department of Food Safety and Quality Assurance, College of Food and Dairy Technology, Tamil Nadu Veterinary and Animal Sciences University, Chennai, India.

\begin{abstract}
Millet is one of the foremost dry season safe crops in terms of world agrarian generation. Sorghum and pearl millet are the major millet crops developed in India. Sorghum and Pearl millet grain were analysed for proximate composition. The results found that the moisture, protein, crude fat, ash, carbohydrate, crude fibre and energy value of sorghum grain were $11.08 \mathrm{~g} / 100 \mathrm{~g}, 10.27 \mathrm{~g} / 100 \mathrm{~g}, 3.26 \mathrm{~g} / 100 \mathrm{~g}, 1.12 \mathrm{~g} / 100 \mathrm{~g}, 72.91 \mathrm{~g} / 100 \mathrm{~g}, 1.65 \mathrm{~g} / 100 \mathrm{~g}$ and $359.19 \mathrm{kcal}$ respectively. The minerals, for example, calcium $(\mathrm{Ca})$, phosphorous $(\mathrm{P})$, iron $(\mathrm{Fe})$ and zinc $(\mathrm{Zn})$ of sorghum grain were 21.40, 210.03, 4.14, and $1.65 \mathrm{mg} / 100 \mathrm{~g}$. The moisture, protein, crude fat, crude fibre, ash, carbohydrate and energy value of pearl millet was $12.20 \mathrm{~g} / 100 \mathrm{~g}, 11.59 \mathrm{~g} / 100 \mathrm{~g}, 4.4 \mathrm{~g} / 100 \mathrm{~g}, 1.55 \mathrm{~g} / 100 \mathrm{~g}, 1.6 \mathrm{~g} / 100 \mathrm{~g}, 68.64 \mathrm{~g} / 100 \mathrm{~g}$ and $360.6 \mathrm{kcal} / 100 \mathrm{~g}$ respectively. Ca, $\mathrm{P}, \mathrm{Fe}$ and Znmineral content of pearl millet was 30.40, 292.08, 8.45 and $7.14 \mathrm{mg} / 100 \mathrm{~g}$ respectively. The proximate analysis revealed that these grains have appreciable amounts of nutrients.

KEYWORDS: Millet, Sorghum, Pearl Millet, Proximate Composition.
\end{abstract}

Received: Feb 11, 2021; Accepted: Mar 31, 2021; Published: Apr 19, 2021; Paper Id.: IJASRJUN20212

\section{INTRODUCTION}

Worldwide millet generation was evaluated around 27.83 million tons (FAOSTAT, 2014). India is the biggest producer (41.04\%) within the world taken after by Nigeria (11.94\%). Maharashtra, Rajasthan and Karnataka are the highest states of millets development in India. Role of millets in total food grain production of India decreased from $22.17 \%$ to $6.94 \%$ over the final six decades from 1950-51 to 2011-12. These days, more than 50\% of the millet production is finding its way to substitute uses as opposed to its utilization as it were as a staple (Malathiet al., 2016).

Tripathi and Platel, (2011) stated that micronutrient deficits, particularly iron, iodine, vitamin A and zinc are widely predominant in developing and some developed countries. Nutrient deficiencies could be alleviated by fortification of cereal grains with millets.

Sorghum is the ruler of millet cereals and is one of the imperative nourishment crops in dry lands of tropical Africa, India and China (Vannalliet al., 2008). Sorghum production, India ranks second positions in the world and first with esteem to provincially significant crops like millets and pseudo-cereals. "Sorghum is the central staple food of Maharashtra, and is additionally a vital nourishment of Karnataka, Madhya Pradesh, Tamil Nadu and Andhra Pradesh" (Chavan et al., 2017).

India is the biggest manufacturer of pearl millet within the world. Gujarat, Rajasthan and Haryana are conventional pearl millet developing states of India. Pearl millet (Pennisetum typhoideum) is the foremost broadly developed sort of millet all through the world and is prevalent to major cereals healthfully viz., high-quality 
proteins, fat and minerals such as calcium, iron and zinc. Additionally, it is additionally a wealthy source of dietary fiber and small-scale supplements (Malik et al., 2002).

Pearl millet is usually cultivated as grain and fodder crop in dry land. India is the foremost commercial producer of pearl millet followed by China and Nigeria. The entire pearl millet production in India is around 8.3 MT (ICRISAT, 2013). Around 90 million people depend upon pearl millet as food source in the form of porridge, flat breads or chapatti (CGIAR, 2015).

\section{MATERIAL \& METHODS}

All the glasswares utilized in this research were cleaned carefully. Chemicals and reagents used in this work were of analytical grade (AR) and freshly prepared reagents. Proximate analysis of grains is the determination of the major components which include moisture, lipids (fat), ash (minerals), protein, carbohydrate and fibre. Procedures recommended by Association of Official Analytical Chemist (AOAC, 1984) were used for this analysis.

\section{RESULTS \& DISCUSSION}

Sorghum and pearl millet grain proximate composition are presented in Table1. The results uncovered that protein contents in sorghum was $10.27 \mathrm{~g} / 100 \mathrm{~g}$. The value was concurrent with the findings of Jimoh and Abdullahi, (2017) who reported that protein content ranged from 6.23 to $13.81 \%$. These findings are in accordance with the findings of Torres et al., (2006) of $9.01-11.43 \%$; Asha et al.,(2005) of 10.40\% and Abu, (2001) of $10.08-15.55 \%$ protein. The differences in protein substance of the several sorghum samples are chiefly due to the nature and absence of vital element required for plant life (Arnon, 1995 and Jimoh \& Abdullahi, 2017). Belhadi et al.,(2013) testified that the white sorghum grains contain crude protein values were $12.27 \pm 0.18 \%$.

The carbohydrate content was found at $72.91 \mathrm{~g} / 100 \mathrm{~g}$ and comparable with the range of $65.57-76.28 \% / 100 \mathrm{~g}$ obtained by Jimoh and Abdullahi, (2017). Nutritionally, carbohydrate substance is present in sorghum grains in the form of starch. As sorghum, like other cereals, is rich in starch, around $70 \%$ and has fabulous potential for industrial applications (Zhan et al., 2003). The values of sorghum starch were $65.05 \pm 0.19 \%$ for the white sorghum grains (Belhadiet al.,2013).

The sample showed a lipid content value of $3.26 \%$, which is in agreement with the research works carried out by Torres et al., (2006) who reported a lipid value of 2.76\% - 3.75\%; Gassem \& Osman, (2003) of 3.58 - 4.47\% and Abu, (2001) of $2.22-3.65 \%$ (Jimoh \& Abdullahi, 2017).

The ash content was $1.12 \%$ for sorghum millet. The ash content of the sample might be influenced by the nature and number of ions existing within the soil from which plants draw its supplements (Akinsola, 1993). Gassem \& Osman, (2003) conveyed that $1.90-1.97 \%$ of ash content which is higher than the result attained in this study, but Abu (2001) stated that $1.01-1.56 \%$ of ash content which correlates well with the results found in this work.

The mean crude fibre content of the sorghum sample was $1.65 \%$. This is identical to the findings of Gassem \& Osman, (2003) who reported the crude fibre content ranged from 1.64 - 2.66\%; Asha et al.,(2005) of 1.21\% and Abu et al., (2001) of $1.04-2.81 \%$ (Jimoh \& Abdullahi, 2017).

The pearl millet, crude protein value was $11.59 \mathrm{~g} / 100 \mathrm{~g}$. "The recommended dietary allowance of (RDA) protein is $60 \mathrm{~g} /$ adult". The findings were comparable with those gotten by Subramanian et al., (1986) who testified a range of 8.6$15.6 \%$ crude protein for 20 pearl millet cultivars (Abdalla et al., 1998). The results were concurrent with the findings of 
Sullivan et al., (1990) who reported 8 to $19 \%$ of protein content present in pearl millet. Millet protein may be a great source of fundamental amino acids but for lysine and threonine and is generally high in methionine content (Ratnavathi, 2016).

The carbohydrate content was found to be $68.64 \mathrm{~g} / 100 \mathrm{~g}$ and reasonably comparable with the range of 59.4 to 69.5g/100g achieved by Uprety and Austin, (1972).

The crude fat content is $4.4 \%$ and these values are within the range of 4-9\% detailed by Desikachar, (1975) and Elyaset al., (2002). Fat gives remarkably a great source of energy and helps in transport of fat-soluble vitamins protecting and ensures inside tissues and contribute to important cell processes (Jones et al., 1985 and Akpabio \& Ikpe, 2013).

Crude fibre in food is a sign of the level of non-digestible carbohydrate and lignin. The crude fibre value of $1.55 \mathrm{~g} / 100 \mathrm{~g}$ in pearl millet is suitable since it ruins assimilation of glucose, fat and enhances digestibility and diminished supplement utilization (Oladiji et al.,2005 and David et al., 2014).

Ash content was $1.6 \mathrm{~g} / 100 \mathrm{~g}$ and values obtained were within the range 1.2-2.4\% as reported by Hadimani and Malleshi, (1995) and Elyaset al., (2002). Ash in food contributes the leftover residues after all the wetness has been removed as well as organic material have been incinerated at a temperature of about $550^{\circ} \mathrm{C}$. Ash content is commonly measured to be a quantity of the mineral content of the original food (Onwuka, 2005 and David et al., 2014).

The proximate composition showed that pearl millet has abundance protein, crude fat and total ash content than sorghum, but carbohydrate is high in sorghum millet when compared with pearl millet.

Table 1: Proximate Composition of Sorghum and Pearl Millet (Mean \pm SD)

\begin{tabular}{|l|l|l|}
\hline Component $(G / 100 g$ Dry Basis) & Sorghum Millet & Pearl Millet \\
\hline Moisture & $11.08 \pm 0.164$ & $12.20 \pm 0.16$ \\
\hline Protein $(\mathrm{g})(\%$ of $\mathrm{N} \times 6.25)$ & $10.27 \pm 0.04$ & $11.59 \pm 0.02$ \\
\hline Crude Fat $(\mathrm{g})$ & $3.26 \pm 0.05$ & $4.4 \pm 0.03$ \\
\hline Total Ash $(\mathrm{g})$ & $1.12 \pm 0.005$ & $1.6 \pm 0.01$ \\
\hline Carbohydrate $(\mathrm{g})$ & $72.91 \pm 0.427$ & $68.64 \pm 0.166$ \\
\hline Crude Fibre $(\mathrm{g})$ & $1.65 \pm 0.022$ & $1.55 \pm 0.042$ \\
\hline Energy $(\mathrm{Kcal})$ & $359.19 \pm 0.023$ & $360.6 \pm 0.069$ \\
\hline Calcium, $(\mathrm{mg} / 100 \mathrm{~g})$ & $21.40 \pm 0.030$ & $30.40 \pm 0.190$ \\
\hline Phosphorous, $(\mathrm{mg} / 100 \mathrm{~g})$ & $210.03 \pm 0.016$ & $292.08 \pm 0.046$ \\
\hline Iron, $(\mathrm{mg} / 100 \mathrm{~g})$ & $4.14 \pm 0.019$ & $8.45 \pm 0.023$ \\
\hline Zinc, $(\mathrm{mg} / 100 \mathrm{~g})$ & $1.65 \pm 0.023$ & $7.14 \pm 0.021$ \\
\hline
\end{tabular}

@-average of six trials

On account of pearl millet being higher in protein, lipid and energy than those from sorghum and maize showing that pearl millet may be utilized in novel nourishment applications. The normal protein and fat contents of millet at $12 \%$ moisture are $11.8 \%$ and $4.8 \%$ respectively (FAO, 1995). These are similar to values for sorghum (10.4\% protein and $3.1 \%$ fat).

The supplement composition of pearl millet in comparison to other cereal grains appears generally high gross energy substance of roughly $363 \mathrm{Kcal} / 100 \mathrm{~g}$. This high energy content is due to the high-fat substance of the grain which is related to the large size. Compared to maize, Pearl millet has higher arginine, threonine, valine, isoleucine and lysine.

Minerals such as calcium (Ca), phosphorus (P), iron (Fe), and zinc ( $\mathrm{Zn}$ ) content of sorghum millet and pearl millet grains were found to be $21.40,210.03,4.14$ and $1.65 \mathrm{mg} / 100 \mathrm{~g}$ and $30.40,292.08,8.45$ and $7.14 \mathrm{mg} / 100 \mathrm{~g}$ respectively. 


\section{CONCLUSIONS}

The proximate analysis revealed that sorghum and pearl millet contain appreciable amounts of nutrients. This study proved that sorghum and pearl millet contain high protein, energy, fibre and essential minerals. Hence, these grains have considerable potential to be used as a good nutrient source in developing versatile food products and beverages in food industry.

\section{ACKNOWLEDGEMENT}

The authors thanks to the College of Food and Dairy Technology, Tamilnadu Veterinary and Animal Sciences University, Chennai for providing facility to carry out this research work.

\section{REFERENCES}

1. Abdalla, A. A., El Tinay, A. H., Mohamed, B. E. \& Abdalla, A. H. (1998). Proximate composition, starch, phytate and mineral contents of 10 pearl millet genotypes. Food chemistry, 63(2), 243-246.

2. Abu, A. E., Aba, D. A., Chindo, P. S., Ango, K. M. \&Maigida, D. N. (2001). Biochemical evaluation of ten sorghum cultivars compared with Wheat for baking characteristics. Institute of Agricultural Research, Zaria.

3. Akinsola, R. O. (1993). Nutritional value of some poultry feeds in Nigeria (Doctoral dissertation, M. Sc. Dissertation, Bayero University, Kano).

4. Akpabio, U. D. \& Ikpe, E. E. (2013). Proximate composition and nutrient analysis of Aneilemaaequinoctiale leaves. Asian Journal of Plant Science and Research, 3(2), 55-61.

5. AOAC, (1984). Official method of analysis of the association of the analytical chemists., $14^{\text {th }}$ Edition, Washington DC, USA, pp.152-162.

6. Arnon, D. I. (1995). Criteria of essentiality of inorganic micro-nutrients for plants with special reference to molybdenum in trace elements in plant physiology, Chronica Botanical Company, Waltham mass. Chronica Botanical Company, 120.

7. Asha, V. B., Geetha, K., Sheela, K. \& Dhanapal, G. N. (2005). Nutritional composition of sorghum and moth bean incorporated traditional recipes. Journal of Human Ecology, 17(3), 201-203.

8. Belhadi, B., Djabali, D., Souilah, R., Yousfi, M. \& Nadjemi, B. (2013). Three small-scale laboratory steeping and wet-milling procedures for isolation of starch from sorghum grains cultivated in Sahara of Algeria. Food and Bioproducts Processing, 91(3), 225-232.

9. Chavan, U. D., Nirmal, S. V., Shinde, M. S., Pawar, G. H., Gadakh, S. R. \& Dalvi, U. S. (2017). Nutritional quality of hybrid sorghum genotypes. International Journal of Current Microbiology and Applied Sciences, 6(2), 586-592.

10. David, B. M., Michael, A., Doyinsola, O., Patrick, I. \& Abayomi, O. (2014). Proximate composition, mineral and phytochemical constituents of Eleusine coracana (finger millet). International Journal of Advanced Chemistry, 2(2), 171-174.

11. Desikachar, H. S. R(1975). Processing of maize, sorghum and millets for food uses.

12. Elyas, S. H., El Tinay, A. H., Yousif, N. E. \& Elsheikh, E. A. (2002). Effect of natural fermentation on nutritive value and in vitro protein digestibility of pearl millet. Food chemistry, 78(1), 75-79.

13. F. A. O. (1995). Sorghum and Millets in Human Nutrition. Food and Nutrition Series FAO Rome Italy Pp 49-86.

14. FAOSTAT: (2014) http://faostat3.fao.org/home/E. Food and Agriculture Organization, Rome. 
15. Gassem, M. A. \& Osman, M. A. (2003). Proximate composition and the content of sugars, amino acids and anti-nutritional factors of three sorghum varieties. Agricultural Research Center, King Saud University, Research Bulletin, (125), 5-19.

16. Hadimani, N. A., Ali, S. Z. \& Malleshi, N. G. (1995). Physico-chemical composition and processing characteristics of pearl millet varieties. Journal of Food Science and Technology, 32(3), 193-198.

17. ICRISAT. http://www.icrisat.org.International Crops Research Institute for the Semi-Arid Tropics, 2015.

18. Jimoh, W. L. O. \& Abdullahi, M. S. (2017). Proximate analysis of selected sorghum cultivars. Bayero Journal of Pure and Applied Sciences, 10(1), 285-288.

19. Jones, M.M, D. O Johnson, J. T, Netlerville J. I Wood \& M.D. Joesten (1985). Chemistry and Society, $5^{\text {th }}$ ed. Saunders College Publishers, USA, 521-577.

20. Malathi, B., Appaji, C., Reddy, G. R., Dattatri, K. \& Sudhakar, N. (2016). Growth pattern of millets in India. Indian Journal of Agricultural Research, 50(4).

21. Malik, M., Singh, U. \& Dahiya, S. (2002). Nutrient composition of pearl millet as influenced by genotypes and cooking methods. Journal of food science and technology (Mysore), 39(5), 463-468.

22. Onwuka, G.I. (2005). Food analysis and instrumentation. Theory and practice. Naphthalic prints, Surulere, Lagos, Nigeria. 129-130.

23. Ratnavathi, C. V. (2016). Nutritional Qualities \& Value Addition of Millets. Millets and Sorghum: Biology and Genetic Improvement, 323.

24. Subramanian, V., Jambunathan, R., \& Ramaiah, C. D. (1986). Physical and chemical characteristics of pearl millet grains and their relationship to roti quality. Journal of Food science, 51(4), 1005-1008. Sullivan, T. W., Douglas, J. H., Andrews, D. J., Bond, P. L., Hancock, J. D., Bramel-Cox, P. J. \& Brethour, J. R. (1990). Nutritional value of pearl millet for food and feed.

25. Torres C.T, T. E, M. G Alanis Guzman \&R.Maiti, (2006). Relation between Nutritional Composition and Anatomical Parameter in Sorghum Retrieve, vol. 3.

26. Tripathi, B. \&Platel, K. (2011). Iron fortification of finger millet (Eleucine coracana) flour with EDTA and folic acid as cofortificants. Food Chemistry, 126(2), 537-542.

27. Uprety, D. C. \& Austin, A. (1972). Varietal differences in the nutrient composition of improved bajra (pearl millets) hybrids. Bulletin of Grain Technology, 10(4), 249-255.

28. Vannalli, S., Kasturiba, B., Naik, R. K. \& Yenagi, N. (2008). Nutritive value and quality characteristics of sorghum genotypes. Karnataka Journal of Agricultural Sciences, 20(3), 586-588.

29. Zhan, X., Wang, D., Tuinstra, M. R., Bean, S., Seib, P. A. \& Sun, X. S. (2003). Ethanol and lactic acid production as affected by sorghum genotype and location. Industrial Crops and Products, 18(3), 245-255. 
